American Journal of Applied Sciences 5 (3): 179-183, 2008

ISSN 1546-9239

(C) 2008 Science Publications

\title{
Oil Palm Biomass As Potential Substitution Raw Materials For Commercial Biomass Briquettes Production
}

\author{
${ }^{1}$ A.B.Nasrin, ${ }^{1}$ A.N.Ma, ${ }^{1}$ Y.M.Choo, ${ }^{1}$ S.Mohamad, ${ }^{1}$ M.H.Rohaya,${ }^{1}$ A.Azali and ${ }^{2}$ Z.Zainal \\ ${ }^{1}$ Engineering \& Processing Research Division, \\ MPOB, No. 6, Persiaran Institusi,B.B.Bangi, 43000 Kajang. \\ ${ }^{2}$ School of Mechanical Engineering, Universiti Sains Malaysia, \\ 14300 Nibong Tebal, Pulau Pinang
}

\begin{abstract}
Palm oil industry generates vast amount of palm biomass. Converting palm biomass into a uniform and solid fuel through briquetting process appears to be an attractive solution in upgrading its properties and add value. In this study, raw materials including empty fruit bunch (EFB), in powder and fibre forms, palm kernel expeller (PKE) and sawdust were densified into briquettes at high temperature and pressure using screw extrusion technology. The briquettes were analysed to determine its physical and chemical properties, mechanical strength and burning characteristics. It was found that briquettes made either from $100 \%$ pulverized EFB or mixed with sawdust exhibited good burning properties. EFB fibre and PKE, due to their physical properties, were recommended to be blended with sawdust in producing quality briquettes. In overall, converting palm biomass into briquettes has increased its energy content and reduced moisture content about minimum of 5\% and 38\% respectively compared to its raw materials. The properties of palm biomass briquettes obtained from the study were compared to the commercial sawdust briquettes properties and to the minimum requirements of DIN 51731. The details of the study were highlighted in this paper. Palm biomass briquettes can become an important renewable energy fuel source in the future.
\end{abstract}

Keywords : oil palm, briquettes, biomass fuel, screw extrusion technology, renewable energy

\section{INTRODUCTION}

Malaysian palm oil industry has grown tremendously over the last 4 decades and since then, it has maintained its position as the leading world's country in the production of palm oil. Nevertheless, the industry has also generated vast quantities of palm biomass, mainly from milling and crushing palm kernel. The types and amounts of these biomass generated in year 2005 are tabulated in Table 1.

Generally, most of these biomass can be used as combustion fuels. Currently, the shell and fibre are the main sources of energy in palm oil mills. These fuels are burnt in boiler to produce steam for electricity generation to be used in the milling process. However, EFB and PKC, due to its physical properties and demands, are not normally utilized as fuel. In order to make use of the resource and expand its usage as fuel in various industries and applications, raw oil palm biomass should be treated and upgraded into uniform and useful fuels. Upgrading the properties of these abundantly available palm biomass can be done in many ways and one of the proven methods is via briquetting process.

Densification or briquetting is the process of compacting the biomass residue into a uniform solid fuel called briquettes. It has higher density and energy content, and less moist compared to its raw materials. Briquetting of biomass can be done using various techniques, either with or without binder addition.

Biomass briquettes are mostly used for cooking, heating, barbequeing and camping in the countries such as USA, EU, Australia, Japan, Korea and Taiwan. In the developing countries, biomass briquettes are mainly for household usage only. For larger commercial scale, it can be used as fuel in producing steam, district heating and electricity generation.

In Malaysia, the briquette industry was started with wood wastes, mainly in the form of sawdust ${ }^{[3]}$. Most of the local sawdust briquettes or charcoal briquettes are exported for oversea markets ${ }^{[3]}$.. The products are rarely

Corresponding Author: Nasrin Abu Bakar, Engineering and Processing Research Division,MPOB, No. 6, Persiaran Institusi,B.B.Bangi, 43000 Kajang. Malaysia 
Am. J. Applied Sci., 5 (3): 179-183, 2008

Table 1: Palm biomass generated in year 2005

\begin{tabular}{lcccc}
\hline \multicolumn{1}{c}{ Biomass } & $\begin{array}{c}\text { Quantity, million } \\
\text { tonnes, } *\end{array}$ & $\begin{array}{c}\text { Moisture Content, } \\
\%^{* *}\end{array}$ & $\begin{array}{c}\text { Calorific Value, } \\
\mathrm{kJ} / \mathrm{kg}^{* *}\end{array}$ & Main uses \\
\hline Fibre & 9.66 & 37.00 & 19068 & Fuel \\
Shell & 5.20 & 12.00 & 20108 & Fuel \\
Empty Fruit & 17.08 & 67.00 & 18838 & Mulch \\
Bunches & & & & Animal feed \\
Palm Kernel & 2.11 & 3.00 & 18900 & \\
Expeller & & & &
\end{tabular}

used in the local market as it could not compete with the availability of cheap fuels such as wood, charcoal and kerosene which are widely used in the rural areas and restaurants ${ }^{[3]}$. This industry has grown impressively for the past few years and indicated that there is good return for investment ${ }^{[3]}$.

Briquetting of palm biomass is new to the millers. The low supply of sawdust and wood residues for briquettes and charcoal briquettes has put palm biomass in the position to be used as substitute for sawdust. Palm biomass can be used $100 \%$ or can be blended with sawdust for the production of briquettes. Therefore, this is an opportunity for the industry to make use of all these wastes for value added products.

\section{METHODOLOGY}

Empty fruit bunch (EFB), palm kernel cake (PKC) and sawdust were used as raw materials. Raw EFB was converted into pulverized and fibre forms. PKC was collected and used as a raw material without any pretreatment process. The properties of the raw materials used were determined and presented in Table 3.

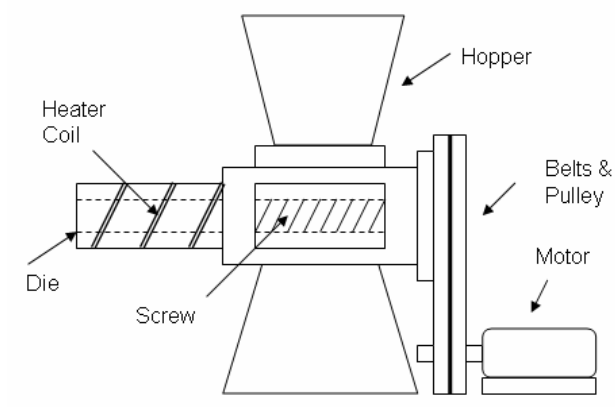

Fig. 1: The typical commercial screw extrusion technology (source: modified from www.ait.ac.th ${ }^{[4]}$ )

Palm biomass briquettes were prepared by using commercial screw extrusion technology available in the sawdust briquettes plant. Through this technology, the biomass was extruded continuously by a screw through a taper die which is heated externally ${ }^{[5]}$. No binder is required as the lignin of biomass that fluidized during the process helps in binding ${ }^{[5]}$. The pressure and temperature applied for the process were about $7 \mathrm{MPa}$ and $150-250^{\circ} \mathrm{C}$ respectively. The typical screw extrusion briquetting machine is illustrated in Fig. 1.

The production trials of palm biomass briquettes were carried out either by using $100 \%$ palm biomass or blending with sawdust. At the beginning, $100 \%$ palm biomass were used as raw material, however if the briquettes could not be formed, sawdust will be gradually added to the palm biomass at the minimum percentage till quality briquettes were produced. The briquettes produced then are analyzed to determine their physical, chemical, mechanical and combustion properties. The results are compared to the commercial sawdust briquettes and to the minimum requirements of DIN $51731^{[6]}$. The descriptions of the study and method or standard used are shown as follow in Table 2. The production process trials of palm biomass briquettes can be summarized in Fig. 2.

\section{RESULTS AND DISCUSSION}

Production Trials: The production trials were carried out using EFB fibres of various sizes, PKC and sawdust. The aims of the productions are to produce binderless palm briquettes without affecting the overall quality of briquettes. The properties of raw materials used were determined as shown in Table 3 .

From the production trials conducted using screw extrusion technology, it was found that $100 \%$ palm biomass briquettes could be made from pulverized EFB. Other palm biomass raw materials are needed to be blended with sawdust in order to form the binderless briquettes. This is due to its fibrous physical properties such as low density and less surface area that hinder the smooth flow ability of biomass and in producing natural lignin as binder. Therefore, they were easily broken into pieces during briquetting or producing a low physical quality of briquettes as shown in Fig. 3a if sawdust was not added. It is recommended that the feeding part of the machine should be modified or binder is added if briquettes are made from these raw materials. 


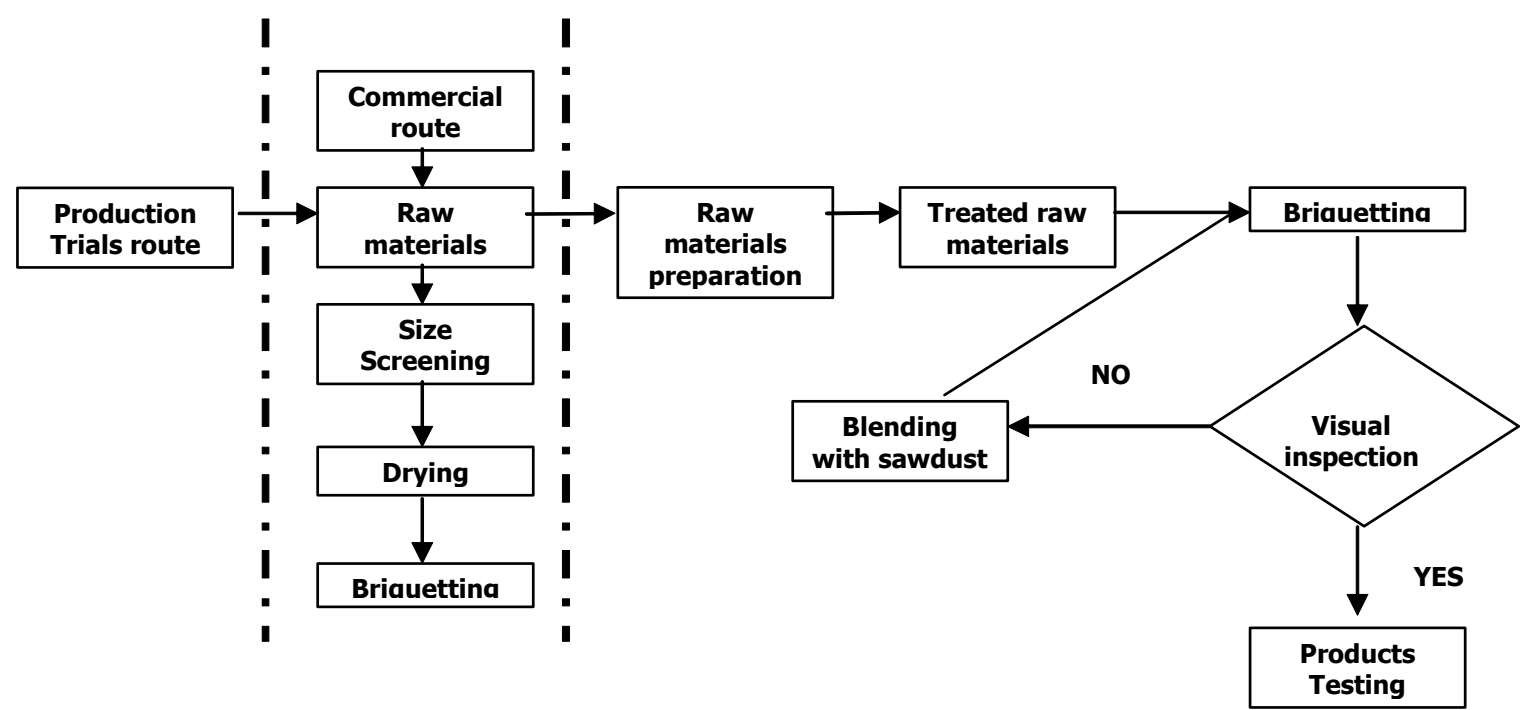

Fig. 2: The palm biomass briquetting production trials approach

Table 2: Methodology and standard for properties study of raw materials and products

\begin{tabular}{ll}
\hline \multicolumn{1}{c}{ Experimental } & \multicolumn{1}{c}{ Standard Method / Methodology } \\
\hline Moisture Content & BS 4289 part 3: 1978 \\
Calorific Value & ASTM 2015 \\
Ash Content & 1SO 1171-97 \\
Mechanical Strength & Compressive and Elasticity Strengths \\
Combustion Analysis & Burning profile \& combustion rate \\
\hline
\end{tabular}

Table 3: Properties of raw materials used for the production trials

\begin{tabular}{lcccc}
\hline \multicolumn{1}{c}{ Raw Material } & $\begin{array}{c}\text { Average Size of } \\
\text { materials }\end{array}$ & $\begin{array}{c}\text { Calorific } \\
\text { Value, kJ/kg }\end{array}$ & $\begin{array}{c}\text { Moisture } \\
\text { Content, \% }\end{array}$ & $\begin{array}{c}\text { Ash } \\
\text { Content, \% }\end{array}$ \\
\hline Pulverized EFB,( PEFB) & $<212 \mu \mathrm{m}$ & 17000 & 12.0 & 2.41 \\
EFB Fibre, (FEFB) & $3 \mathrm{~cm}$ & 16641 & 16.0 & 4.70 \\
EFB Fibre, (FEFB) & $2.5 \mathrm{~mm}$ & 16641 & 14.0 & 4.60 \\
Palm Kernel Cake, (PKC) & $<300 \mu \mathrm{m}$ & 18500 & 3.0 & 3.94 \\
Sawdust, (SD) & $<500 \mu \mathrm{m}$ & 18506 & 10.0 & 2.31 \\
\hline
\end{tabular}

Table 4: The properties and its blending ratios of palm biomass briquettes

\begin{tabular}{|c|c|c|c|c|}
\hline Products (Blending ratio) & & Calorific Value, $\mathrm{kJ} / \mathrm{kg}$ & Moisture content, \% & Ash content, \% \\
\hline $100 \%$ Pulverized EFB & & 17823 & 7.39 & 2.85 \\
\hline $\begin{array}{l}\text { Pulverized EFB + Sawdust } \\
(50 \cdot 50)\end{array}$ & & 18273 & 7.22 & 2.22 \\
\hline $\begin{array}{l}\text { Fibre EFB + sawdust } \\
(40: 60)\end{array}$ & & 18775 & 7.32 & 2.99 \\
\hline $\begin{array}{l}\text { PKC + sawdust } \\
(33: 67)\end{array}$ & & 19534 & 4.60 & 2.35 \\
\hline $\begin{array}{l}\text { PKC }+ \text { Fibre } \\
\text { sawdust(30:5:65) }\end{array}$ & + & 19379 & 5.82 & 2.17 \\
\hline Sawdust (control product) & & 18936 & 6.81 & 1.63 \\
\hline DIN 51731 (minimum) & & 17500 & $<10.0$ & 0.7 \\
\hline
\end{tabular}


(a)
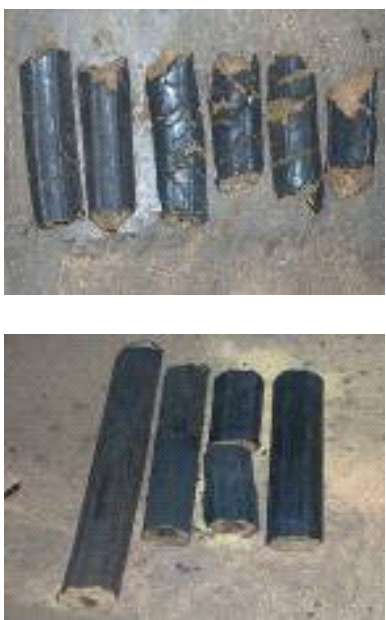

(b)

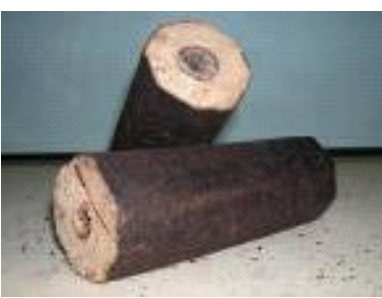

(c)

Fig. 3a: Unacceptable of palm briquettes quality during production trials, Fig .3b \& 3c: Quality palm briquettes for commercial purposes
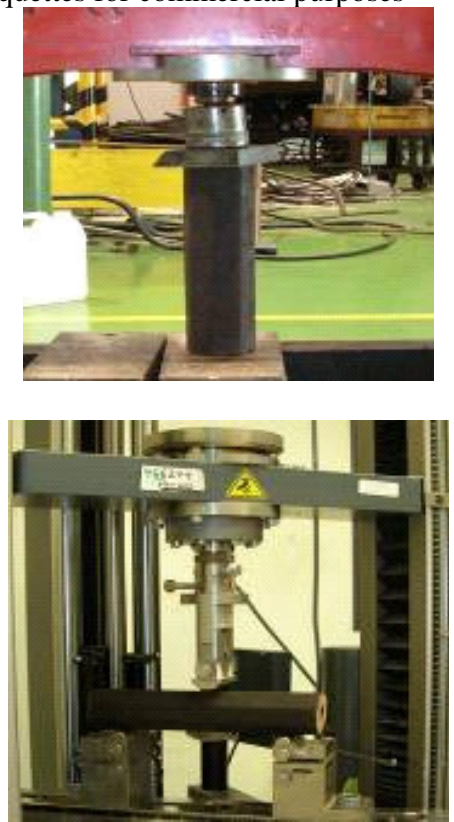

Fig 4: Instruments for compressive and elasticity strength analysis

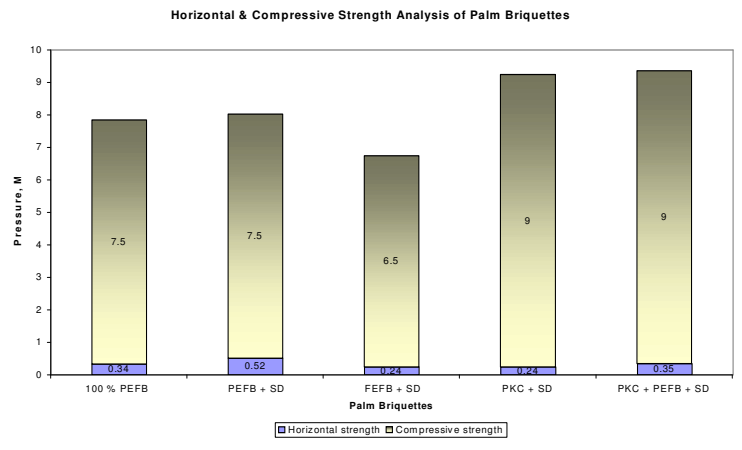

Fig. 5: Results of compressive and elasticity strength analysis of palm briquettes

Products Properties: The preliminary findings of palm biomass briquettes and its blending ratios are tabulated in the Table 4. Results obtained were comparable to the local sawdust briquettes and meet with the minimum requirements of DIN 51731except for ash content. The briquetting process of palm biomass increased its energy content and reduced moisture content about minimum of 5\% and $38 \%$ respectively compared to its raw materials The study also shows that in order to have good physical appearance of briquettes, the minimum blending ratios of sawdust must be at $50 \%$ of total weight.

The quality of produced palm briquettes is shown in Fig. $3 b \& 3 c$. The outer surface of the products generally is partially carbonized. They are made in cylindrical log shape with $490 \mathrm{~mm}$ in length, $55 \mathrm{~mm}$ in diameter, $1.1 \mathrm{~kg}$ each weighing with bulk density of $1300 \mathrm{~kg} / \mathrm{m}^{3}$. The final product size depends on the customer's requirement and normally is marketed at 5 or $10 \mathrm{~kg}$ per pack of briquettes.

Mechanical Strength Analysis: Vertical and horizontal forces were applied to the briquettes. Vertical force or compressive strength analysis of briquettes was determined using a hydraulic press machine, while elasticity strength was conducted by applying force at the middle part in horizontal side of briquettes using Zwick 100 -Tensile Machine. Both testing machines are illustrated as in Fig. 4. The average compressive and horizontal strengths for palm biomass briquettes are $7.9 \mathrm{MPa}$ and $0.34 \mathrm{MPa}$ respectively. It was found that the addition of sawdust improved the strength of palm briquettes and its outer physical surface condition as well. The result of the mechanical strength analysis of palm briquettes are shown in Fig. 5. 


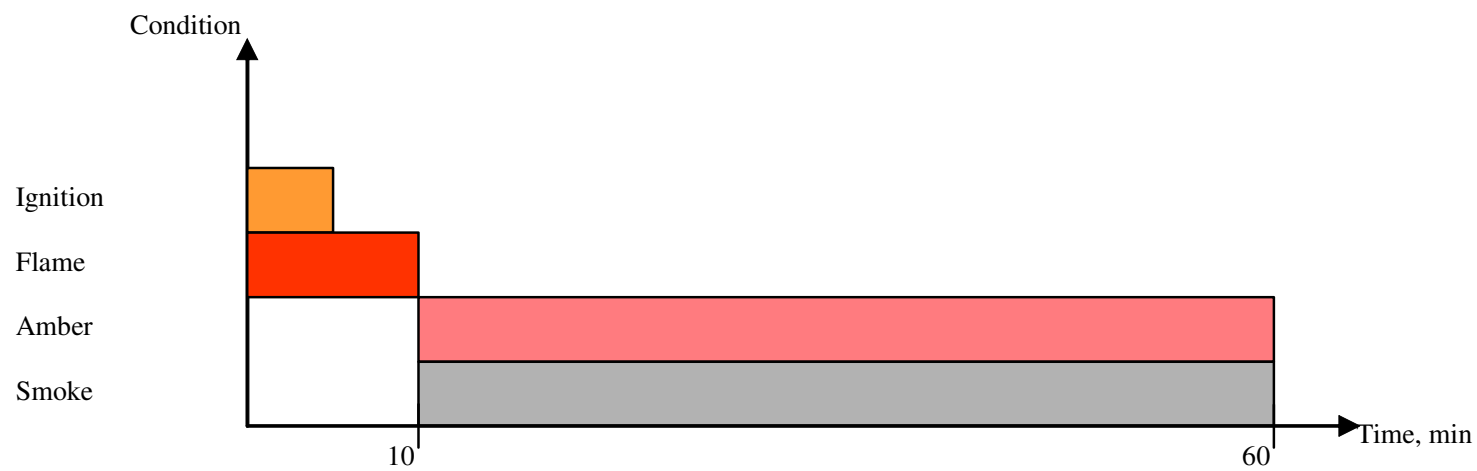

Fig. 6: Burning profile of palm biomass briquettes (source: modified from Pentananunt et al. ${ }^{[7]}$ )

Combustion Analysis: The combustion characteristics of palm briquettes were studied using a typical open air stove as an attempt to simulate the actual combustion situation for domestic heating or cooking. From the analysis, it was found that palm briquettes were not easy to ignite. Therefore, firestarter medium such as kerosene was used to instant the process. The burning profile of palm briquettes is illustrated in Fig. 6. Except for the smoke condition, the profile was similar to results reported earlier for sawdust briquettes and torrefied $\operatorname{wood}^{[7]}$. The average burning rate was recorded at $0.43 \mathrm{~g} / \mathrm{min}$. The analysis also shows that at the normal surrounding air, palm biomass briquettes are capable to generate about $0.13 \mathrm{~kW}$ of thermal output. Although amber and less level of smoke conditions dominated most of the combustion process, however with adequate supply of air, there is a higher tendency of the fuel to re-flaming.

\section{CONCLUSION}

From the experiments carried out, it was generally found that the characteristics of palm biomass briquettes produced from screw extrusion technology, were satisfactory compared to commercial sawdust briquettes. Nevertheless, the results meet the international standards requirements

for export markets. It is recommended that the modification of the machine and addition of binder are necessary in producing quality briquettes. The blending of palm biomass with sawdust can improve its physical, mechanical and combustion properties. Therefore, palm biomass is suitable for substitution in certain ratios of sawdust briquettes production.

Production cost is a barrier for local market. More $R \& D$ activities are still required to make it more cost effective as renewable energy source and for oversea markets.

\section{ACKNOWLEDGEMENT}

The authors wish to thank Director-General of MPOB for his permission to publish this paper. Thanks are also due to all staff of Energy \& Environment Unit and Biomass \& Technology Unit of MPOB for their technical assistance. The cooperation from those industrial partners is also greatly appreciated.

\section{REFERENCES}

1. Economics \& Industry Development Division, MPOB, 2006. Malaysian Oil Palm Statistics 2005, $25^{\text {th }}$ Edition, MPOB Publisher, pp: 23-40

2. Vijaya, S., Chow, M.C. and Ma. A.N.,2004. Energy Database of the Oil Palm. MPOB Palm Oil Engineering Bulletin, 70:15-22

3. Hoi Why Kong, 1995. Wood and Charcoal Briquetting in Malaysia. In: Proceedings of International Workshop on Biomass Briquetting, (eds P.D.Grover and S.K Mishra). pp 68-74. FAO Regional Wood Energy Development Programme

4. www.ait.ac.th

5. P.D.Grover and S.K. Mishra, 1996. Biomass Briquetting: Technology and Practices. FAO Report, United Nations, Bangkok,

6. Deutsches Institut für Normung e.V, 1996 DIN 51731 Testing On Solid Fuels - Compresses Untreated Wood- Requirements and Testing

7. Pentananunt, R., Rahman A.N.M.M. and Bhattacharya, S.C., 1990. Upgrading of Biomass by Means of Torrefaction. Energy, 15(12): 11751179 